\title{
TRENDS IN GROUNDWATER LEVEL CHANGES IN SMALL FOREST CATCHMENTS OF WIELKOPOLSKA
}

\author{
Rafał Stasik', Mariusz Korytowski', Daniel Liberacki' \\ 1 Institute of Land Reclamation, Environmental Development and Geodesy, Poznań University of Life Science, \\ Piątkowska94E St.,60-649 Poznań, e-mail: stasikr@up.poznan.pl, mario@up.poznan.pl, dliber@up.poznan.pl
}

Received: 2016.05.21

Accepted: 2016.06.30

Published: 2016.09.20

\begin{abstract}
Trends in groundwater level changes in small forest catchments located in Wielkopolska region were analysed on the basis on data collected for many years of groundwater levels observations. The observations were carried out from 2000 to 2010 hydrological year in Marianka Siemiańska and Laski forest district as well as in Puszcza Zielonka. The groundwater levels were measured in soil profiles located in different forest habitats: fresh, moist and swamp forest. Changes in groundwater level determined using the Mann-Kendall test were found to differ significantly between the catchment studied. Statistically insignificant decrease in groundwater levels was observed at all forest sites in the catchment area in Marianka Siemiańska forest district. In the catchment area of the Hutka watercourse the groundwater level showed a statistically significant decreasing tendency in Puszcza Zielonka in swamp and fresh mixed coniferous forest. It may indicate a decrease in water resources and implies the need of groundwater level monitoring. A statistically insignificant increase in groundwater level was observed in the wells in moist mixed broadleaved forest in the area of pond catchment in Laski forest district, this trend was interpreted as a result of the clearcutting made in this area.
\end{abstract}

Keywords: small forest catchment, groundwater, Mann-Kendall test.

\section{INTRODUCTION}

The depth of groundwater table is one of the most important indicators of forest environment conditions. The groundwater levels change cyclically as a result of meteorological condition variation in hydrological year period, especially as a result of the amount and distribution of precipitation as well as air temperature [Grajewski and Okoński 2007, Kosturkiewicz et al. 2002, Liberacki 2003, Liberacki and Szafrański 2013, Szafrański 1993, Szafrański and Korytowski 2004]. Groundwater is closer to the ground surface in winter half-year and its decreases as a result of stand transpiration in summer half-year. [Stasik 2011]. The long-term groundwater levels changes are fundamental from the viewpoint of evaluation of state and vitality of forest environment. They can result from unfavourable climate changes [Grajewski et al. 2013, Kędziora et al. 2014], the methods of economic forest use and logging [Hotta et al. 2010, Finnegan et al. 2014, Korytowski 2013] and differentiation of the water needs of forest stands, trees size [Dawson 1996] and trees age.

The aim of the study was to analyse groundwater level changes in small forest catchments in Wielkopolska region in diversified forest stand conditions.

\section{STUDY AREA, MATERIALS AND METHODS}

The study was carried out in three small forest catchments of Wielkopolska. Two of them are located in the forests of Siemianice Forest Experimental Farm (LZD). The first one is located in Marianka Siemiańska forest district (Rakowski Ditch catchment, which is denoted as G-ditch on the map) and the second catchment (of pond no. 5) in Laski forest district (Figure 1). 
According to Geografia Regionalna Polski [Kondracki 2011] the forests of LZD Siemianice are located in Wieruszowska Plateau. This area is located at South Wielkopolska Lowland and makes its southern frontier. In terms of hydrography, the object is a part of Pomianka River catchment area, which is a left-bank tributary of the Prosna River. The forests of Marianka Siemiańska and Laski districts are located in north-east part of Oleśnicka Plain mesoregion, Silesia nature woodland country, according to the 2010 nature-forestry regionalisation [Zielony and Kliczkowska 2012]. Permeable sands, loamy sands and less frequently sandy loams dominate in the soil cover.

A characteristic feature of the catchment located in Marianka Siemiańska forest district is the dominant area of swamp forest stands (about 51\% of wooded catchment area). Moist forest stands have also a significant share (31\%) in the wooded catchment area. The total fresh forest stands occupy $18 \%$ of the area. Fresh forest stands take $96 \%$ of the area of catchment of no. 5 pond and moist forest stands occupy the rest of the area.
The Hutka watercourse catchment area is located in Wielkopolsko-Kujawska Lowland, in Poznańska Plateau at the margin of Puszcza Zielonka Landscape Park. It is within Wielkopolsko-Pomorska woodland country in Wielkopolskie Lakeland mesoregion according to the 2010 nature-forestry regionalisation [Zielony and Kliczkowska 2012]. Sands, loams and outwash sands are there the parent materials. Fresh forest stand occupies the most part of catchment area, while swamp and moist stands occupy only $4 \%$ and $3 \%$ of the area.

The procedure of the study included:

- systematic groundwater levels measurement, carried out once a week, and periodically once in two weeks,

- daily measurements of precipitation sums and air temperature, carried out in LZD Siemianice and Puszcza Zielonka Arboretum.

The most complete and the longest time series of measurements at piezometric wells were chosen for analysis. The series of data was taken

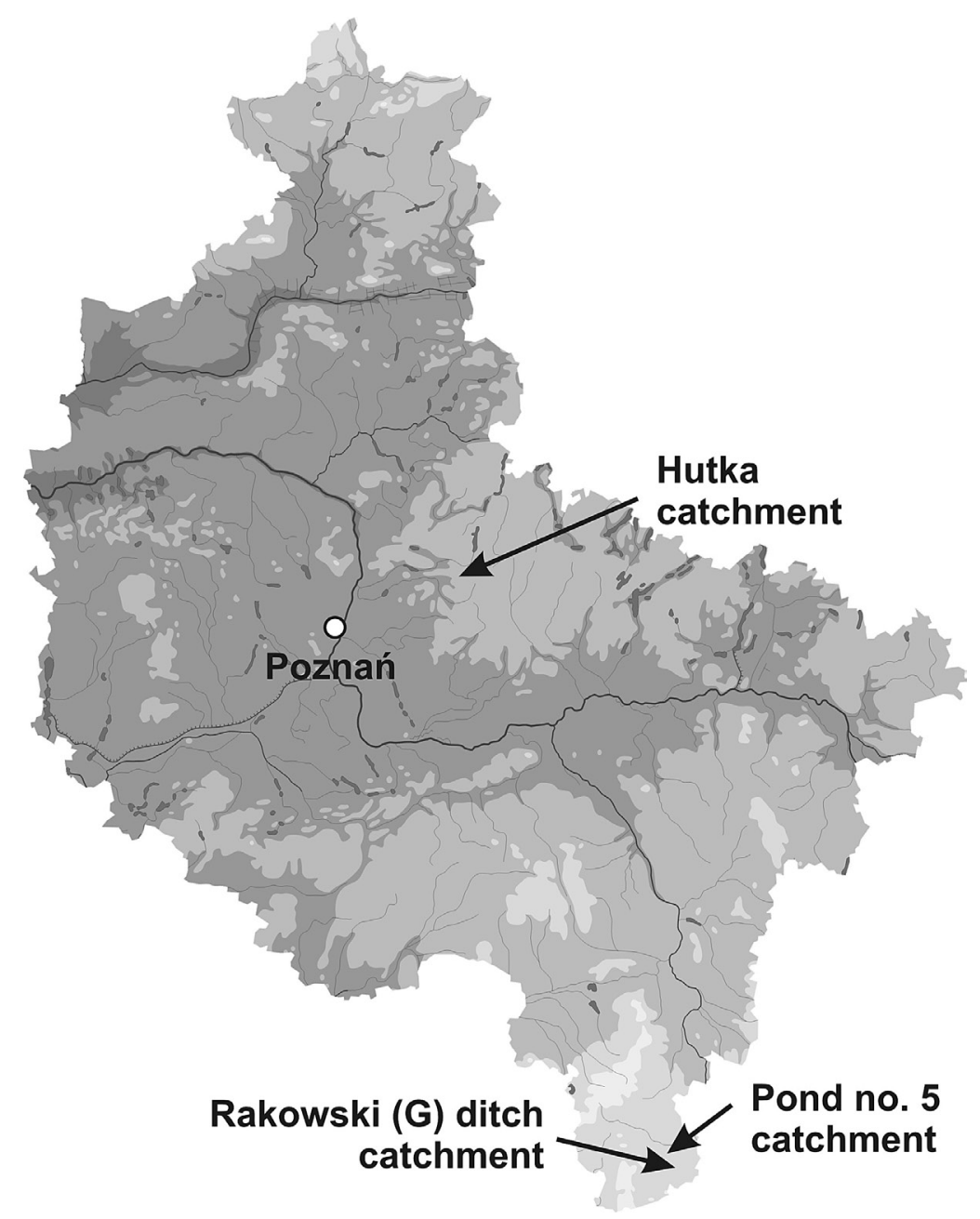

Figure 1. Location of analysed catchment against Wielkopolska map 
from 2000-2010 hydrological period. From Gditch catchment the data series from G1.3 well in ash-alder swamp forest (O1J), G2.11 well in moist mixed broadleaved forest (LMw), G4.4 in moist mixed coniferous forest (BMw), G3.14 well in fresh mixed broadleaved forest (LMśw), and G3.9 well in fresh mixed coniferous forest (BMśw) were chosen for analysis (Figure 2). Data series from D1.1 and D1.2 well in moist mixed broadleaved forest $(\mathrm{LMw})$ were chosen from pond no. 5 catchment. From the catchment area of Hutka watercourse, the data series from $\mathrm{H} 3$ well in alder carr forest $(\mathrm{Ol}), \mathrm{H} 13$ well in fresh mixed coniferous forest (BMśw) and H4 well in fresh broadleaved forest (Bśw) were analysed (Figure 2).

The Mann-Kendall test was used to analyse groundwater level trends in chosen piezometric wells as well as the trends of changes in precipitation and air temperature. The Mann-Kendall test is a non-parametric statistical test for identification trends in time series data [Hirsch et al. 1982, Gilbert 1987, Maksymiuk et al. 2008, Banasik et al. 2013]. The Mann-Kendall test is defined as:

$$
\mathrm{S}=\sum_{\mathrm{k}=1}^{\mathrm{n}-1} \sum_{\mathrm{j}=\mathrm{k}+1}^{\mathrm{n}} \operatorname{sgn}\left(\mathrm{x}_{\mathrm{j}}-\mathrm{x}_{\mathrm{k}}\right)
$$

where:

$$
\begin{aligned}
& \operatorname{sgn}\left(x_{j}-x_{k}\right)=\left\{\begin{array}{l}
1 \text { if }\left(x_{j}-x_{k}\right)>0 \\
0 \text { if }\left(x_{j}-x_{k}\right)=0 \\
-1 \text { if }\left(x_{j}-x_{k}\right)<0
\end{array}\right. \\
& \left.x_{1}, x_{2}, \ldots, x_{n}\right\}- \text { data points }
\end{aligned}
$$

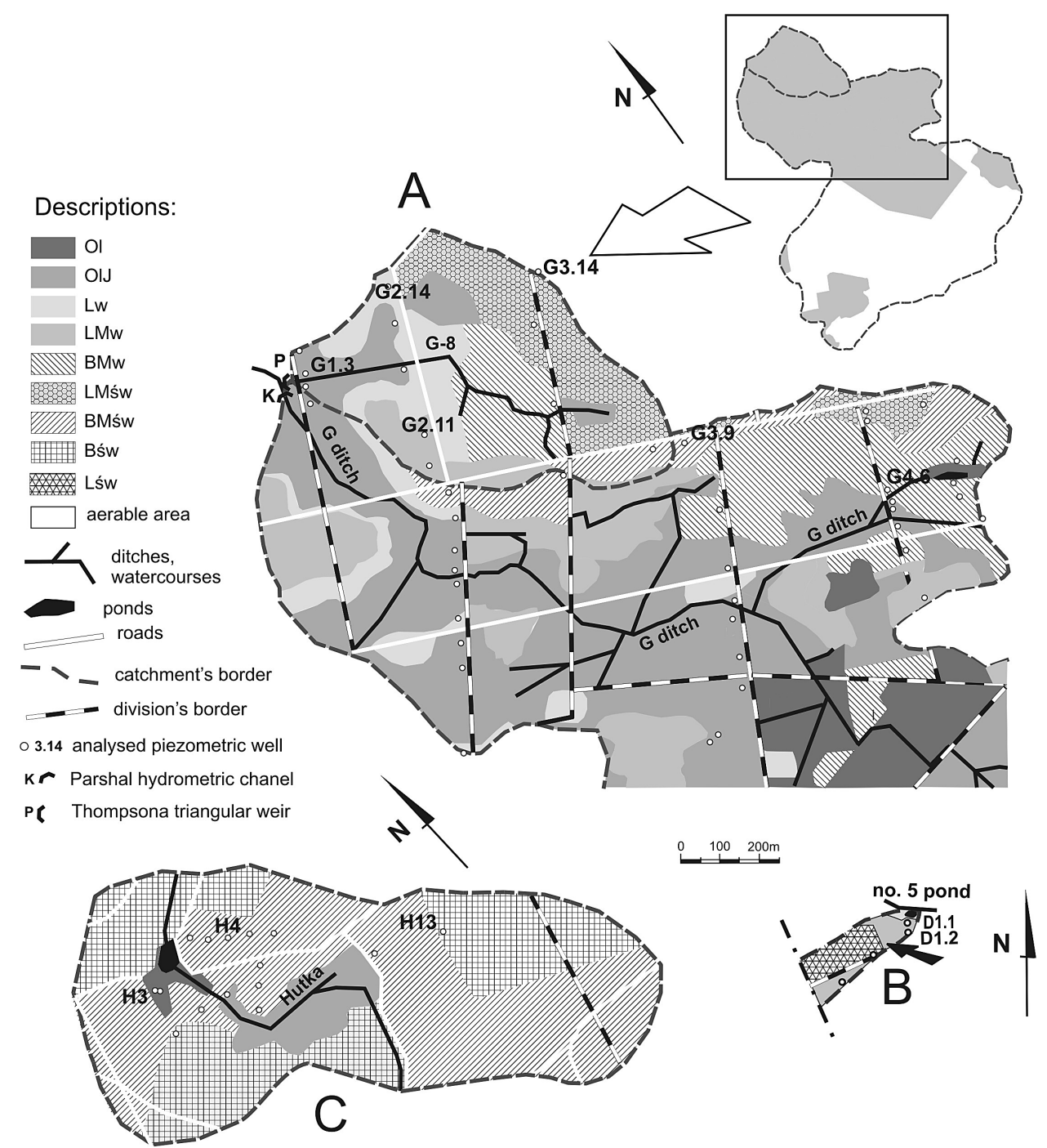

Figure 2. Forest habitat maps of analysed parts of G ditch (A) pond no. 5. (B) and Hutka watercourse (C) with wells location. Descriptions of forest site types: Ol - alder carr forest, OlJ - ash-alder swamp forest, Lw - moist broadleaved forest, $\mathrm{LMw}$ - moist mixed broadleaved forest, $\mathrm{BMw}$ - moist mixed coniferous forest, LMśw - fresh mixed broadleaved forest, BMśw - fresh mixed coniferous forest, Bśw - fresh coniferous forest Lśw - fresh broadleaved forest 
If $\mathrm{S}$ value is close to zero it indicates no-trend hypothesis. S value significantly higher than zero indicates an upward trend, meanwhile $\mathrm{S}$ value significantly lower than zero suggests a downward trend. It should be noted that groundwater levels are measured in relation to the ground surface, which means that higher value of groundwater level is equal to deeper water-table position. Therefore, considering Mann-Kendall statistics, a positive value of $\mathrm{S}$ indicates decreasing of groundwater table and a negative $\mathrm{S}$ value indicates its increase. The tests were made separately for each month of the period of study and for hydrological years, because groundwater levels change seasonally. The last data from each month were used for monthly trend calculation.

When $Z_{\mathrm{s}}>Z_{\mathrm{kr}}$ than the trend is statistically significant. $Z_{\mathrm{kr}}=1,95$ when confidence level is $\alpha=0.05 . Z_{\mathrm{s}}$ value is calculated according to the following formula:

$$
\mathrm{Z}=\frac{\mathrm{S}-1}{\sqrt{\operatorname{Var}(\mathrm{S})}} \text { when: } \mathrm{S}>0
$$

and

$$
\mathrm{Z}=\frac{\mathrm{S}+1}{\sqrt{\operatorname{Var}(\mathrm{S})}} \text { when: } \mathrm{S}<0
$$

For the time series $n>10$, the variation is calculated from the following formula:

$$
\operatorname{Var}(\mathrm{S})=\frac{1}{18} \mathrm{n}(\mathrm{n}-1)(2 \mathrm{n}+5)
$$

Data from soil-forest site maps contained in Soil-Habitat Assessment of LZD Siemianice [Operat... 1999] and in Forest Sites Assessment of Zielonka Forest Experimental District [Operat... 2002], especially the characteristics of soil and forest site types were also used in the study.

\section{RESULTS AND DISCUSSION}

Results of Mann-Kendall test calculation are presented in Table 1. Positive $\mathrm{S}$ values in all of the wells in individuals forest stands provide downward trend of groundwater level in wells of G-ditch catchment in Marianka forest district in particular months of winter half-years (XI-IV) in the period 2000-2010. Statistically significant downward trends of groundwater levels in the period analysed were observed only in a few months of winter half-year: November - the most frequently, December and January.
Also Figure 3 data point to a downward trend of decreasing ground water table. Exemplary groundwater level course and its linear trends of changes for January in the period studied are shown in Figure 3.

July was the only month of summer half-years in the period of 2000-2010 when a statistically significant trend of groundwater level decrease was observed in G3.14 well located in fresh mixed broadleaved forest. The other positive values of $\mathrm{S}$ statistic were not statistically significant and they were clearly lower than the $\mathrm{S}$ values in winter halfyears. Groundwater levels in May 2010 had the highest impact on $\mathrm{S}$ value for May in the whole period studied as shown in figure 4 . In this month extremely high precipitation $(206 \mathrm{~mm})$ was observed, which was the cause of groundwater level growth in this period. In fresh forest sites in May 2010 the groundwater levels were close to the land surface, while usually in this month they are much deeper in relation to land surface.

The results of Mann-Kendall statistics calculation for the amount of precipitations and air temperature shown in table 1 indicate that only in January a statistically significant trend was observed. The $\mathrm{S}$ value of -1 calculated for yearly precipitation in the period 2000-2010 indicates no-trend in precipitation changes, whereas the $\mathrm{S}$ value calculated for yearly average air temperature indicates statistically significant downward trend in the period analysed. So it can be assumed that the observed statistically insignificant slight downward trend of groundwater levels is not connected with precipitation nor average air temperature.

Values of Mann-Kendall test statistics calculated for the wells located in the Hutka watercourse catchment indicate a downward trend in groundwater level (Table 2). In two from the three analysed wells statistically significant trends in the period 2000-2010 were ascertained - in H3 well in alder carr forest as well as in H13 well in fresh mixed coniferous forest. In $\mathrm{H} 3$ well a statistically insignificant trend was ascertained only for August, whereas in H13 for May, June, July and September. Yearly downward trends in groundwater level changes calculated by MannKendall were statistically significant in the wells $\mathrm{H} 3, \mathrm{H} 13$ and H4. The trend revealed by the data from $\mathrm{H} 4$ well, located in broadleaved fresh forest, in hydrological year in the period 2000-2010 was not statistically significant. However the high $\mathrm{S}$ value calculated for $\mathrm{H} 4$ well indicates a downward trend in groundwater level changes. 
Table 1. Results of Mann-Kendall statistic (S) for groundwater levels in wells of G-ditch catchment, precipitation $(\mathrm{P})$ and air temperature $(\mathrm{T})$ measured in Siemianice meteorological station, for individual months and hydrological years in hydrological period 2000-2010

\begin{tabular}{|c|c|c|c|c|c|c|c|}
\hline \multirow{3}{*}{ Period } & \multicolumn{5}{|c|}{ G-ditch catchment } & \multirow{2}{*}{\multicolumn{2}{|c|}{$\begin{array}{c}\text { Siemianice meteorologica } \\
\text { station }\end{array}$}} \\
\hline & \multirow{2}{*}{$\begin{array}{c}\text { G1.3 } \\
\text { OIJ }\end{array}$} & \multirow{2}{*}{$\begin{array}{l}\text { G2.11 } \\
\mathrm{LMw} \\
\end{array}$} & \multirow{2}{*}{$\begin{array}{l}\text { G4.6 } \\
\text { BMw }\end{array}$} & \multirow{2}{*}{$\begin{array}{l}\text { G3.14 } \\
\text { LMśw } \\
\end{array}$} & \multirow{2}{*}{$\begin{array}{c}\text { G3.9 } \\
\text { BMśw }\end{array}$} & & \\
\hline & & & & & & $P$ & $T$ \\
\hline $\mathrm{XI}$ & +24 & +26 & $+29^{*}$ & +26 & $+27^{*}$ & -7 & +9 \\
\hline XII & +21 & $+32^{*}$ & $+36^{*}$ & $+28^{*}$ & $+37^{*}$ & +15 & -9 \\
\hline I & +18 & $+34^{*}$ & $+39^{*}$ & $+31^{*}$ & +25 & $+28^{*}$ & -19 \\
\hline II & +16 & +13 & +12 & +17 & +15 & -7 & -19 \\
\hline III & $+31^{*}$ & +9 & +26 & +17 & +4 & -7 & -17 \\
\hline IV & +16 & +4 & +14 & +13 & +6 & -7 & -11 \\
\hline V & $-27^{*}$ & +3 & +10 & +3 & +5 & +1 & $-33^{*}$ \\
\hline $\mathrm{VI}$ & -11 & -8 & -1 & -10 & -9 & +3 & -3 \\
\hline VII & +1 & +5 & +11 & $+35^{*}$ & +9 & -5 & +17 \\
\hline VIII & +2 & +11 & +10 & +19 & +7 & -9 & -21 \\
\hline IX & +14 & +8 & +10 & +18 & +8 & -11 & -5 \\
\hline$x$ & +11 & +13 & +13 & +13 & +4 & +3 & $-27^{*}$ \\
\hline XI-X & +10 & +13 & +17 & +18 & +12 & -1 & $-29^{*}$ \\
\hline
\end{tabular}

* statistically significant trend.

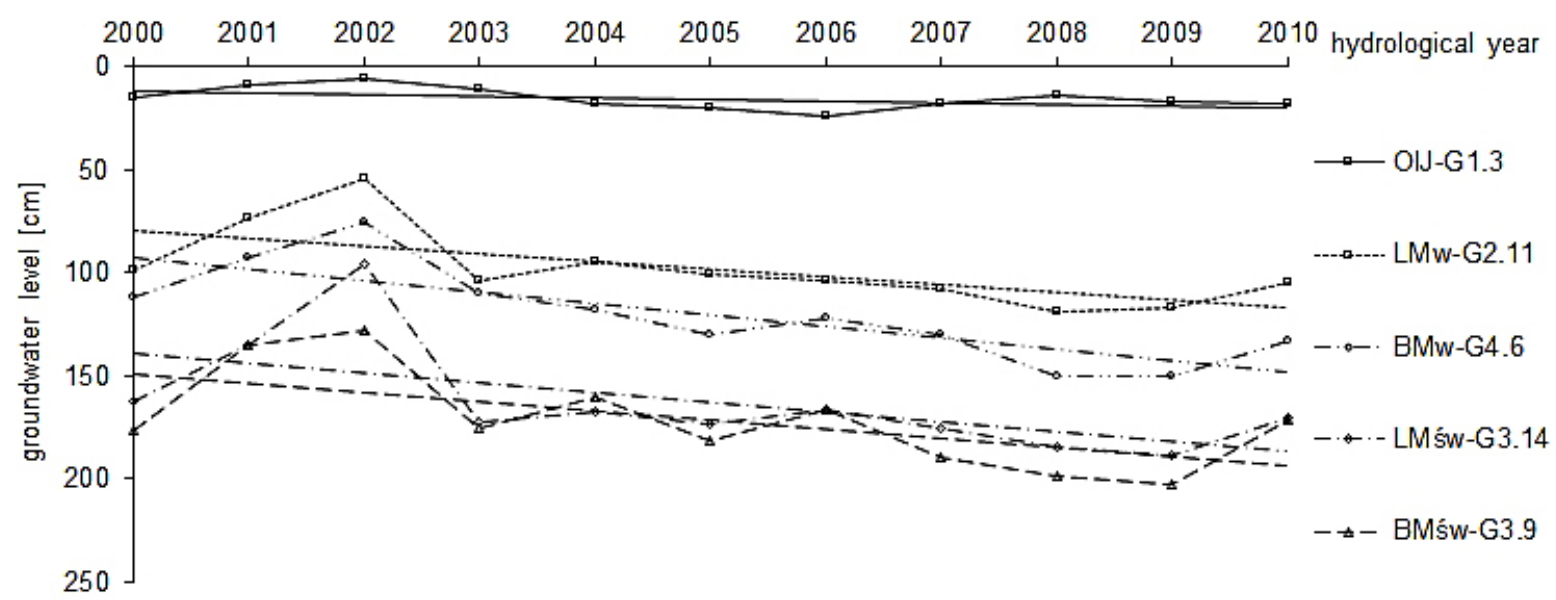

Figure 3. Groundwater levels and linear trend of their changes in chosen wells of G-ditch catchment, calculated for January from the period 2000-2010

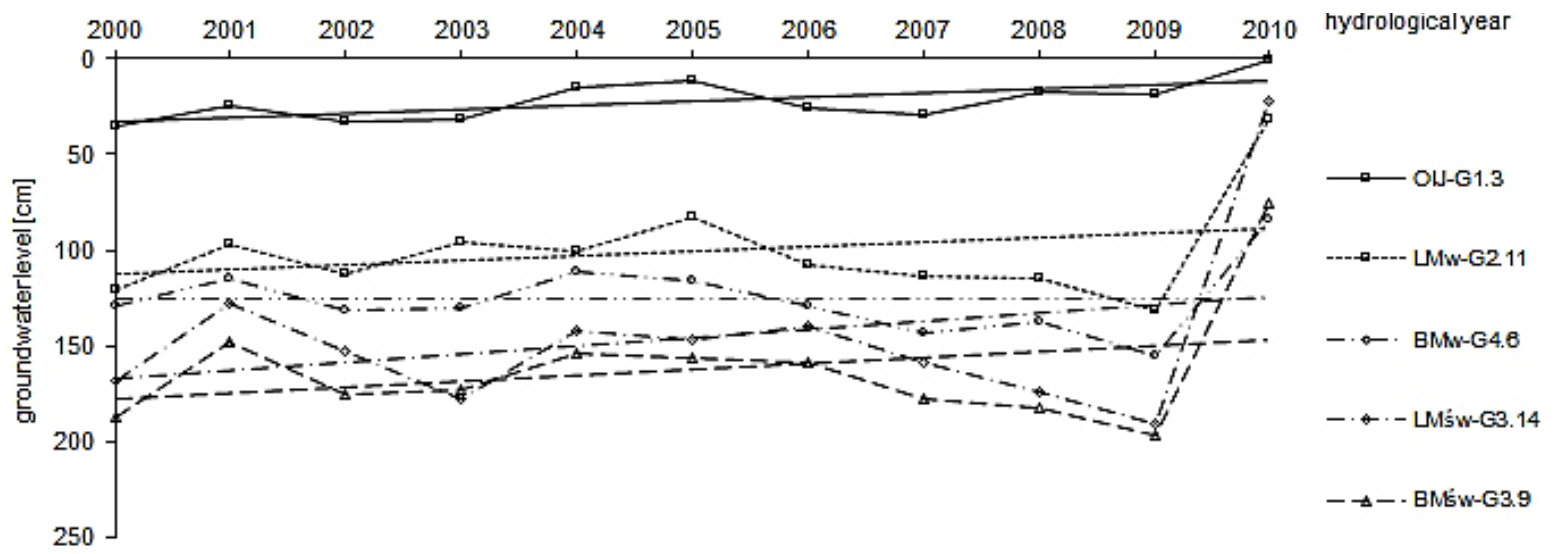

Figure 4. Groundwater levels and linear trends in their changes in chosen wells of G-ditch catchment, calculated for the month of May in the period 2000-2010 
Table 2. Results of Mann-Kendall statistic (S) for groundwater in wells in the Hutka catchment area, for precipitation $(\mathrm{P})$ and air temperature $(\mathrm{T})$ measured in Puszcza Zielonka Arboretum meteorological station, for individual months and hydrological years in the hydrological period 2000-2010

\begin{tabular}{|c|c|c|c|c|c|}
\hline \multirow{3}{*}{ Period } & \multicolumn{3}{|c|}{ Hutka watercourse catchment } & \multirow{2}{*}{\multicolumn{2}{|c|}{$\begin{array}{c}\text { Meteorological station } \\
\text { Puszcza Zielonka Arboretum }\end{array}$}} \\
\hline & \multirow{2}{*}{$\begin{array}{l}\mathrm{H} 3 \\
\mathrm{OI}\end{array}$} & \multirow{2}{*}{$\begin{array}{c}\text { H13 } \\
\text { BMśw }\end{array}$} & \multirow{2}{*}{$\begin{array}{c}\text { H4 } \\
\text { Bśw }\end{array}$} & & \\
\hline & & & & $P$ & $T$ \\
\hline $\mathrm{XI}$ & $+33^{*}$ & $+42^{*}$ & +18 & -3 & 7 \\
\hline XII & $+39^{*}$ & $+41^{*}$ & $+29^{*}$ & -15 & -12 \\
\hline 1 & $+39^{*}$ & $+43^{*}$ & $+28^{*}$ & -7 & -15 \\
\hline II & $+37^{*}$ & $+41^{*}$ & $+28^{*}$ & -11 & -12 \\
\hline III & $+40^{*}$ & $+34^{*}$ & +23 & +11 & +2 \\
\hline IV & $+37^{*}$ & $+30^{*}$ & $+35^{*}$ & -9 & +8 \\
\hline $\mathrm{V}$ & $+35^{\star}$ & +17 & $+36^{*}$ & $+31^{*}$ & -20 \\
\hline VI & $+35^{*}$ & +16 & $+30^{*}$ & -7 & +4 \\
\hline VII & $+35^{*}$ & +23 & +17 & +3 & +5 \\
\hline VIII & +26 & $+29^{*}$ & +11 & +5 & -16 \\
\hline IX & $+28^{*}$ & +22 & +8 & +7 & +14 \\
\hline$x$ & $+33^{*}$ & $+29^{*}$ & +12 & -11 & -23 \\
\hline XI-X & $+35^{*}$ & $+31^{*}$ & +23 & +1 & -11 \\
\hline
\end{tabular}

* statistically significant trend.

Statistically significant downward trend in groundwater level changes in $\mathrm{H} 4$ was observed in four month of winter half-year and in two months of summer half-year. No trend in precipitation changes was noted in the Hutka catchment area (Table 2). The $S$ value of +1 was calculated for yearly precipitation. The downward trend in air temperature within the period studied 20002010 was not statistically significant. Therefore, a decrease in groundwater levels was not caused by changes in precipitation and air temperature. Continuation of such a trend over a longer period could indicate progressive decrease in water resources in the Hutka catchment. However, such conclusion should be documented by groundwater levels monitoring for longer periods and at more wells also in the other forest site types in the catchment.

In pond no. 5 catchment area, there were no statistically significant trends in groundwater level changes (Table 3) in D1.1 as well as in D1.2 well. However in comparison with Mann-Kendall statistic values calculated for wells in G-ditch and Hutka watercourse catchments, for pond no. 5 catchment area the $\mathrm{S}$ values were negative which suggests rising of groundwater level. Considerable increase in the groundwater level in November 2006 is seen in Figure 5. It was caused by the clearcutting made in the moist mixed broadleaved forest where both wells are located. This clearcut- ting was made in the period from February to October 2006 in the total area of 0,74 ha.

Therefore directly after clearcutting groundwater levels raised significantly in this forest stand. Such results were also confirmed by Korytowski [2013].

Analysis of the groundwater level changes and characteristic groundwater levels in periods before and after clearcutting proved an increase in groundwater levels in the clearcutting area in pond no. 5 catchment.

\section{CONCLUSIONS}

The results of Mann-Kendall test calculations indicate downward trends in groundwater levels in all forest site types of G-ditch catchment in individual months of winter half-years in multiyear 2000-2010. However, the trends were mostly statistically insignificant. The $\mathrm{S}$ values for the months of summer half-years as well as for hydrological year were lower in comparison with those for months of winter half-years. They also were statistically insignificant.

Downward trends in groundwater levels in the wells of Hutka watercourse catchment area were observed in the period analysed. The trends were statistically significant in two from three wells studied, located in alder carr forest and 
Table 3. Results of Mann-Kendall statistic (S) for groundwater in the wells from the catchment area of no. 5 pond, for precipitation $(\mathrm{P})$ and air temperature $(\mathrm{T})$ measured in Siemianice meteorological station, for individual months and hydrological years in the hydrological period 2000-2010

\begin{tabular}{|c|c|c|c|c|}
\hline \multirow{2}{*}{ Period } & \multicolumn{2}{|c|}{ Pond no. 5 catchment } & \multicolumn{2}{c|}{ Siemianice meteorological station } \\
\cline { 2 - 5 } & D1.1 & D1.2 & P \\
\cline { 2 - 4 } XI & LMw & LMw & -7 & +9 \\
\hline XII & -9 & -3 & +15 & -9 \\
\hline I & -23 & -3 & $+28^{*}$ & -19 \\
\hline II & 0 & +5 & -7 & -19 \\
\hline III & -15 & 0 & -7 & -17 \\
\hline IV & -14 & +1 & -7 & -11 \\
\hline V & -7 & -3 & +1 & $-33^{*}$ \\
\hline VI & -22 & -10 & +3 & -3 \\
\hline VII & -17 & -14 & -5 & +17 \\
\hline VIII & -14 & -7 & -9 & -21 \\
\hline IX & -15 & -4 & -11 & -5 \\
\hline X & -11 & -5 & +3 & $-27^{*}$ \\
\hline XI-X & -25 & -14 & -1 & $-29^{*}$ \\
\hline
\end{tabular}

* statistically significant trend.

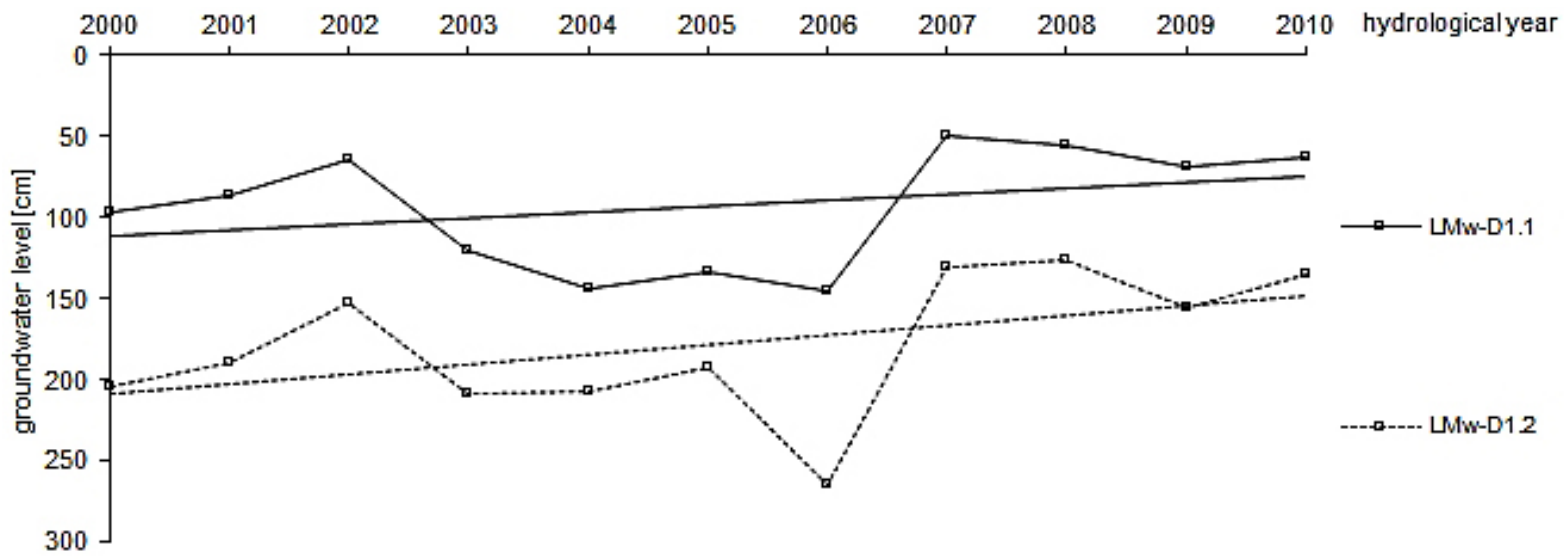

Figure 5. Groundwater levels and linear trend in their changes in chosen wells from no. 5 pond catchment area, calculated for November from the data for the period 2000-2010

fresh mixed coniferous forest. The decrease in the groundwater levels was not connected with changes in the meteorological conditions. It could indicate progressive decrease in water resources in the Hutka catchment area. The results indicate the need for continuation of groundwater levels monitoring over longer period and at more forest site types.

Inconsiderable trend of rising the groundwater levels in moist mixed broadleaved forest in pond no. 5 catchment was observed. This trend was statistically insignificant. The increase in groundwater levels in the wells was caused by clearcutting made in this area.

\section{REFERENCES}

1. Banasik K., Hejduk L., Hejduk A., Kaznowska E., Banasik J., Byczkowski A. 2013. Wieloletnia zmienność odpływu z małej zlewni rzecznej w regionie Puszczy Kozienickiej. Sylwan 157 (8), 578-586.

2. Dawson T. E. 1996. Determining water use by trees and forest from isotopic, energy balance and transpiration analyses: the roles of tree size and hydraulic lift, Tree Physiology 16, 263-272.

3. Finnegan J., Regan J.T., Fenton O., Lanigan G.J., Brennan R.B., Healy M.G. 2014. The short-term effects of management changes on watertable position and nutrients in shallow groundwater in a harvested peatland forest. Journal of Environmental 
Management 142, 46-52.

4. Grajewski S., Okoński B. 2007. Zmienność stanów wód gruntowych w różnowiekowych drzewostanach leśnych siedlisk bagiennych, Infrastruktura i ekologia terenów wiejskich, nr 1/2007, PAN, Kraków, 91-99.

5. Gilbert R. O. 1987. Statistical method for environmental pollution monitoring, chapt. 16.4 MannKendall Test, 208-217.

6. Grajewski S., Miler A. T., Krysztofiak-Kaniewska A. 2013. Zmiany stanów wód gruntowych w Puszczy Zielonka w okresie 1970-2009, Rocznik Ochrona Środowiska t. 15. 1594-1611.

7. Hirsch R. M., Slack J. R., Smith R. A. 1982. Techniques of trend analysis for monthly water quality data, Water Resources Researches, vol. 18, no. 1, 107-121.

8. Hotta N., Tanaka N., Sawano S., Kuraji K., Shiraki K., Suzuki M. 2010. Changes in groundwater level dynamics after low-impact forest harvesting in steep, small watersheds. Journal of Hydrology $385,120-131$.

9. Kędziora A., Kępińska-Kasprzak M., Kowalczak P., Kundziewicz Z. W., Miler A. T., Pierzgalski E., Tokarczyk T. 2014. Zagrożenia związane z niedoborem wody, Nauka 1, 149-172.

10. Kondracki J. 2011. „Geografia regionalna Polski” Wydawnictwo Naukowe PWN Warszawa, pp. 444.

11. Korytowski M. 2013. Analiza zmian stanów wód gruntowych po wycięciu drzewostanu w siedlisku lasu mieszanego wilgotnego na przykładzie Leśnictwa Laski. Rocznik Ochrona Środowiska, t. 15, Koszalin 2015, 1274-1286.

12. Kosturkiewicz A., Czopor S., Korytowski M., Stasik R., Szafrański Cz. 2002. Stany wody gruntowej i siedliska w małej zmeliorowanej zlewni leśnej. Rocz. AR Pozn. 338. Melior. Inż. Śród. 22., 41-53.

13. Liberacki D. 2003. Dynamika zmian poziomu wód gruntowych w różnych siedliskach leśnych małej zlewni nizinnej. Kształtowanie i ochrona środowiska leśnego. Wyd. AR Poznań, 134-140.

14. Liberacki D. Szafrański Cz. 2013. Tendencje zmian położenia zwierciadła wody gruntowej w wybranych zlewniach na obszarze Puszczy Zielonka. Rocznik Ochrona Środowiska t. 15. 2425-2436.

15. Maksymiuk A., Furmańczyk K., Ignar S., Krupa J, Okruszko T. 2008. Analiza zmienności parametrów klimatycznych i hydrologicznych w dolinie rzeki Biebrzy, Przegląd naukowy Inżynieria i Kształtowanie Środowiska nr 3 (41), 59-68.

16. Operat glebowo siedliskowy i fitosocjologiczny LZD Siemianice. 1999. Zakład Usług Ekologicznych i Urządzeniowo Leśnych Poznań.

17. Operat typów siedliskowych lasu, roślinności rzeczywistej i potencjalnej Nadleśnictwa Doświadczalnego Zielonka według stanu z dnia 28.06.2002.

18. Stasik R. 2011. Stany wód i ich amplitudy w ciekach w małych zlewniach leśnych w roku wilgotnym na przykładzie zlewni Rowu Rakowskiego. Rocznik Ochrona Środowiska, t. 13, Koszalin, 1951-1960.

19. Szafrański Cz. 1993. Gospodarka wodna gleb terenów bogato rzeźbionych i potrzeby ich melioracji. Rocz. AR Poznań. Rostr. Nauk. pp. 244.

20. Szafrański Cz., Korytowski M. 2004. Gospodarka wodna zlewni śródleśnego oczka wodnego. Rocz AR w Poznaniu, seria Melior. i Inż. Środ, 25, 557-564.

21. Zielony R., Kliczkowska A. 2012. Regionalizacja przyrodniczo-leśna Polski 2010. Centrum Informacyjne Lasów Państwowych. Warszawa, pp. 356. 